\title{
Hyperthyroidism with normal serum total T4, T3, and thyroid binding protein concentration
}

\author{
JF CARO, NG SLOANE, AND JA GLENNON \\ From the Department of Medicine, Thomas Jefferson University, Philadelphia, Pennsylvania 19107, USA
}

SUMMARY A 60-year-old woman, free of other disease, with severe clinical hyperthyroidism had normal total serum T4 with elevated free T4 concentration and T3 resin uptake characteristic of hyperthyroidism, with thyroid binding globulin (TBG) deficiency. However, serum TBG concentration as determined by immunoassay was normal, suggesting that the biochemical defect affecting the T4 binding sites did not affect its antigenicity. Her total and free serum T3 levels were low-normal with a markedly elevated reverse T3 concentration. These findings, in the presence of clinical hyperthyroidism, are consistent with an impairment in peripheral conversion of T4 to T3, apparently, in this case, due only to long-standing severe hyperthyroidism.

Most patients with hyperthyroidism have high total serum T4 and T3 concentrations. There are times when only one of these hormones is elevated, namely, T3 ${ }^{1}$ or T4 thyrotoxicosis. ${ }^{2}$ When hyperthyroidism is associated with a deficiency of thyroxine-binding globulin (TBG), T4 is normal, ${ }^{3}$ and in the reported cases in which T3 was measured, this hormone was either normal ${ }^{4}$ or elevated. ${ }^{5} 6$

In the hyperthyroid patient described below, normal total serum T4 and T3 concentration with normal thyroid binding protein concentration were associated with elevated serum free $\mathrm{T} 4$ and $\mathrm{T} 3$ resin uptake. The serum free T3 concentration was lownormal but the serum reverse T3 was markedly elevated.

These findings are consistent with a decreased binding affinity of thyroid binding globulin and an impairment in peripheral conversion of T4 to T3.

\section{Case report}

A 60-year-old woman had had a thyroid nodule since early childhood. She had gradually developed fatigue, heat intolerance, insomnia, and nervousness over a five-year period. She had lost $20 \mathrm{lb}(9.0 \mathrm{~kg})$ over the preceding year and for one week she had developed dyspnoea, palpitations, diarrhoea and vomiting. She had taken no medications during her illness.

Physical examination revealed a thin, apprehensive, and tremulous woman in moderate respiratory distress. Her pulse was irregularly irregular at

Received for publication 4 April 1979
$170 / \mathrm{min}$, BP was $150 / 80 \mathrm{mmHg}$, respirations were $28 / \mathrm{min}$, and temperature was $39^{\circ} \mathrm{C}$. A stare and lidlag were present but no exophthalmos. A firm, symmetrical nodule, estimated to be $4 \mathrm{~cm}$ in diameter, was palpable in the left lower lobe of the thyroid gland. Chest $x$-ray was compatible with early congestive heart failure. An electrocardiogram showed atrial fibrillation with a ventricular rate of 180 / $\mathrm{min}$. There was no clinical or laboratory evidence of any chronic or acute illness other than severe hyperthyroidism. After removal of blood for thyroid function studies, a standard thyroid releasing hormone (TRH) stimulation test failed to elevate her initial thyroid stimulating hormone (TSH) level. She was treated with sodium iodide, propylthiouracil, frusemide, and propranolol with clinical improvement in 48 hours. One month later, and three days after stopping antithyroid medication, a 24-hour ${ }^{131} \mathrm{I}$ uptake (131IU) was $60 \%$ and a thyroid scan showed a 3-4 cm hot nodule in the left lower lobe of the thyroid with suppression of the remainder of the gland. A treatment dose of $10 \mathrm{mCi}$ of ${ }^{131} \mathrm{I}$ was given, and propranolol was continued for one month. Three months later the patient was clinically euthyroid. Repeat thyroid function tests are shown along with the initial values in the Table, which represent the average of at least two determinations.

\section{Material and methods}

Total T4 and T3 were measured by radioimmunoassay. ${ }^{78} \mathrm{~T} 3 \mathrm{RU}$ was performed by the method of Sterling and Tabachnik. ${ }^{9}$ Thyroxine-binding prealbumin (TBPA) was determined by the method of Becker. ${ }^{10}$ 
Patient's thyroid function tests

\begin{tabular}{|c|c|c|c|c|c|c|c|c|c|}
\hline & $\begin{array}{l}T 4 \\
(\mu \mathrm{g} / 100 \mathrm{ml})\end{array}$ & $\begin{array}{l}\text { Free T4 } \\
(\mathrm{ng} / 100 \mathrm{ml})\end{array}$ & $\begin{array}{l}T 3 \\
(\mathrm{ng} / 100 \mathrm{ml})\end{array}$ & $\begin{array}{l}\text { Free T3 } \\
(\mathrm{pg} / 100 \mathrm{ml})\end{array}$ & $\begin{array}{l}r T 3 \\
(\mathrm{ng} / 100 \mathrm{ml})\end{array}$ & $\begin{array}{l}T 3 R U \\
\%\end{array}$ & $\begin{array}{l}T B G \\
(\mathrm{mg} / 100 \mathrm{ml})\end{array}$ & $\begin{array}{l}T B P A \\
(\mu g / 100 \mathrm{ml})\end{array}$ & $\begin{array}{l}T S H \\
(\mu U / m l)\end{array}$ \\
\hline $\begin{array}{l}\text { Before treatment } \\
\text { Three months after }\end{array}$ & $r^{12 \cdot 1}$ & 7 & 85 & 442 & 417 & 42 & $3 \cdot 2$ & 184 & 3 \\
\hline $\begin{array}{c}\text { treatment } \\
\text { Normal values }\end{array}$ & $\begin{array}{l}4 \\
4 \cdot 3-12 \cdot 5\end{array}$ & $\begin{array}{l}1 \cdot 6 \\
1 \cdot 3-3 \cdot 8\end{array}$ & $\begin{array}{l}94 \\
70-204\end{array}$ & $\begin{array}{l}318 \\
230-669\end{array}$ & 33 & 40 & $\begin{array}{l}3 \cdot 0 \\
2 \cdot 1 \cdot 5 \cdot 2\end{array}$ & $\begin{array}{l}210 \\
185-285\end{array}$ & $\begin{array}{r}4 \\
<15\end{array}$ \\
\hline
\end{tabular}

Conversion: traditional to SI units-T4: $1 \mu \mathrm{g} / 100 \mathrm{ml} \approx 12 \cdot 87 \mathrm{nmol} / \mathrm{l}$

T3: $1 \mathrm{ng} / 100 \mathrm{ml} \approx 1.536 \mathrm{nmol} / 1$

The absolute free T4 and T3 were measured by dialysis ${ }^{11}$ and $\mathrm{rT} 3$ and TBG by radioimmunoassay. ${ }^{1213}$ TSH was measured by the assay of Utiger. ${ }^{14}$

\section{Discussion}

The typical clinical picture of elevated T4, high ${ }^{131} \mathrm{IU}$, the negative TRH stimulation test, and the clinical improvement with antithyroid drug and propranolol treatment strongly support the diagnosis of hyperthyroidism in this patient.

The T3RU reflects the total binding activity of serum, and the number or affinity of unoccupied binding sites for thyroid hormones on all the thyroid binding proteins of serum (TBG, TBPA, and albumin). An elevated T3RU with a high-normal serum T4 concentration is consistent with a deficiency of TBG in hyperthyroid patients. ${ }^{1}$ However, concentrations of TBG, TBPA, and albumin were normal. Dilutions of the patient's serum from $1 / 100$ to $1 / 3200$ gave perfectly parallel displacement when compared to standard TBG (Figure), excluding immunological non-identity between standard TBG and the TBG immunoreactivity of our patient.

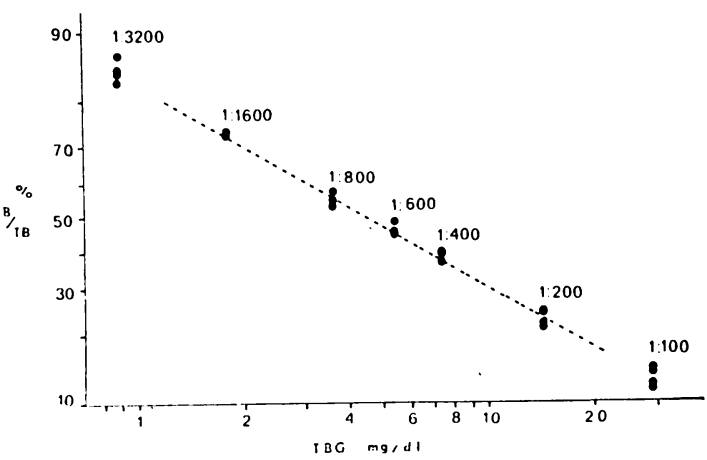

Parallelism of displacement of dilutions of patient serum and $T B G$ standard in $T B G$ radioimmunoassay.

Total triiodothyronine concentration is most often elevated in patients with hyperthyroidism and low
TBG concentration. ${ }^{56}$ Only the case reported by Gerstner and Caplan ${ }^{4}$ had a normal total serum T3 concentration which could not be explained. The low normal total and free $\mathrm{T} 3$ concentration in our patient with a very high rT3 suggests abnormal peripheral diodination of T4 to T3. Serum rT3 concentration in patients with acute or chronic disease having decreased serum T3 concentration is often increased. An increase in serum rT3 concentration also occurs in hyperthyroid patients. This increase is proportional to the increase in serum T4 concentration, indicating that the normal pattern of extrathyroidal T4 conversion to T3 and rT3 is not altered. ${ }^{15}$

However, when patients with hyperthyroidism are acutely or chronically ill as a result of a complicating illness they may have a decreased extrathyroidal formation of $\mathrm{T} 3$ from $\mathrm{T} 4$ with disproportionately high rT3. ${ }^{16}$ Our patient was severely ill as a result of long-term hyperthyroidism alone, which probably was the cause of her abnormal extrathyroidal T4 metabolism. This interpretation is supported by the fact that three months after therapy, when she was euthyroid, rT3 concentration returned to normal limits. The reason for her low total binding protein capacity for T4 with normal thyroid binding protein concentration determined by immunoassay is not clear. She was not taking drugs that are known to decrease TBG affinity. ${ }^{13}$ Braverman et al. ${ }^{17}$ noted decreased TBG binding capacity in hyperthyroid patients which most often returned to normal after euthyroidism was obtained. When our patient was euthyroid with a normal free T4 concentration, she still displayed abnormal thyroid binding protein affinity of serum with an elevated T3RU and low total serum T4 concentration.

Levy et al. ${ }^{13}$ found a correlation between the maximum binding capacity of TBG for T4, measured by reverse flow electrophoresis of whole serum and the T3RU, and those were found to be proportional to the TBG concentration as determined by immunoassay. In patients with congenital TBG abnormality and hyperthyroidism, total serum T4 concentration is normal, and the clinical diagnosis is most often supported by either a high T3RU or a low serum 
TBG maximum binding capacity for T4. The diagnosis would be confirmed by a high free $\mathrm{T} 4$ with low TBG concentration as determined by immunoassay. The normal TBG concentration in our patient with suspected TBG deficiency suggests that the biochemical effect affecting the T4 binding sites does not affect its antigenicity. The patient did not have living relatives who could be studied to see if this was a genetic abnormality, and the possibility exists that her thyroid binding capacity may return to normal later since she was only three months post-treatment.

We appreciate the assistance of Dr Jerald C Nelson, Nichols Institute, San Pedro, California, for performing the assays presented in the Figure, and Miss Sheri Oree for typing the manuscript.

\section{References}

${ }^{1}$ Sterling K, Bellabarba D, Newman ES, Brennar MA. Determination of triiodothyronine concentration in human serum. $J$ Clin Invest 1969;48:1150-8.

${ }^{2}$ Joasoo A. $\mathrm{T}_{4}$ thyrotoxicosis with normal or low serum $\mathrm{T}_{3}$ concentration. A NZ J Med 1975;5:432-4.

${ }^{3}$ Cavalieri RR. Hyperthyroidism and decreased thyroxine binding by serum proteins. $J$ Clin Endocrinol Metab $1961 ; 21: 1455-68$.

- Gerstner JB, Caplan RH. Hyperthyroidism with normal concentrations of total serum thyroxine and triiodothyronine. J Clin Endocrinol Metab 1976:42:64-9.

${ }^{5}$ Wahner HW, Emslander RF, Gorman CA. Thyroid overactivity and TBG deficiency simulating " $\mathrm{T}_{3}$ hyperthyroidism". J Clin Endocrinol Metab 1971;33:93-7.

${ }^{6}$ Horwitz DL, Refetoff S. Graves' disease associated with familial deficiency of thyroxine-binding globulin. J Clin Endocrinol Metab 1977;44:242-7.

${ }^{7}$ Chopra IJ. A radioimmunoassay for measurement of thyroxine in unextracted serum. J Clin Endocrinol Metab 1972;34:938-47.

${ }^{8}$ Chopra IJ, Ho RS, Lam R. An improved radioimmunoassay of triiodothyronine in serum. $J$ Lab Clin Med 1972; 80:729-39.

${ }^{9}$ Sterling K, Tabachnik M. Resin uptake of ${ }^{131} \mathrm{I}_{-} \mathrm{T}_{3}$ as a test of thyroid function. J Clin Endocrinol Metab 1961;21: 456-64.

${ }^{10}$ Becker W. Determination of antisera titres in the single radial immunodiffusion method. Immunochemistry 1969 ; 6:539-46.

11 Ingbar SH, Braverman LE, Dawber NA, Lee, GY. A new method for measuring free thyroid hormone in human serum and an analysis of the factors that influence its concentration. J Clin Invest 1965;44:1679-89.

${ }^{12}$ Chopra IJ. A radioimmunoassay for measurement of $3,3^{\prime}, 5^{\prime}$, triiodothyronine (reverse $\mathrm{T}_{3}$ ). J Clin Invest 1974;54:58392.

${ }^{13}$ Levy RP, Marshall JS, Velayo NL. Radioimmunoassay of human thyroxine binding globulin (TBG). $J$ Clin Endocrinol Metab 1971;32:372-81.

$"$ Utiger RD. Thyrotropin. In: Jaffe BM, Behrman HR, eds. Methods of Hormone Radioimmunoassay. New York: Academic Press, 1974;161-71.

${ }^{15}$ Schimmel M, Utiger RD. Thyroidal and peripheral production of thyroid hormones. Ann Int Med 1977;87 760-8.

${ }^{16}$ Engler D, Donaldson EB, Stockigt JR, Taft P. Hyperthyroidism without triiodothyronine excess: an effect of severe non-thyroidal illness. J Clin Endocrinol Metab 1978;46:77-82.

${ }^{17}$ Braverman LE, Foster AE, Ingbar SH. Thyroid hormone transport in the serum of patients with thyrotoxic Grave's disease before and after treatment. $J$ Clin Invest $1968 ; 47: 1349-57$

Requests for reprints to: Joseph A Glennon, MD, Department of Medicine, Thomas Jefferson University, 1025 Walnut Street, Philadelphia, Pennsylvania 19107, USA. 